\title{
Infant feeding practices and Prevalence of Iron Deficiency Anemia Among Children of 0-5 Years in Ondo State, Nigeria.
}

\author{
$*^{1}$ S.S. Olufemi (RD), ${ }^{2}$ Gbadamosi O.F, ${ }^{1}$ Akinrinmade R., ${ }^{1}$ Oladapo A.A. (RD), \\ ${ }^{I}$ Department of Nutrition and Dietetics, Rufus Giwa Polytechnic, P.M.B. 1019, Owo, Ondo State, Nigeria. \\ Phone no: +23408068596968 \\ ${ }^{2}$ Department of Nutrition \& Dietetics, Federal Polytechnic, Bida,PMB 55, Bida, Niger State.
}

\begin{abstract}
This study was carried to assess the prevalence and death resulting from iron deficiency anemia among children of 0-5 years in Ondo State, Nigeria. This study further examined the contribution of infant feeding practices and dietary intakes of mothers to the prevalence and mortality from iron deficiency anemia. Four State Specialist Hospitals in the State were used for the study.

Data of children mortality and prevalence of iron deficiency anemia from 2005 to 2009 were obtained from the hospital's records. About one hundred and forty (140) well structured questionnaires were administered to mother-child pairs to obtain information on food intakes and feeding practices. Data collected were analyzed using descriptive statistical techniques and T-test. Results revealed the highest prevalence of anemia throughout the State. Amongst the hospitals, the highest prevalence of iron deficiency anemia was in Ondo Town with 27\% (463) children suffered from anemia in 2008. Mortality status from anemia was highest throughout the State in 2005 with 29\% of mortality recorded while State Specialist Hospital, Ondo recorded the highest number of children death in 2009 with $30 \%$ (44) death records. The study equally showed that $54.3 \%$ of mothers adopted the use of blood supplements, 30\% used iron-rich foods and 15\% used local herbs to prevent anemia. $17 \%$ of mothers disliked egg during pregnancy, $20 \%$ meat/fish while $6.4 \%$ dislike milk. Only a few mothers $16.4 \%$ always fed their children with liver, $19.3 \%$ always gave egg while $53.6 \%$ gave milk as complementary foods. Meat/fish intakes of children and child's mortality from anemia in 2006, 2007 and 2008 were negatively significant at $P=0.05$ level. The Author, therefore, concluded that the prevalence and deaths resulting from iron deficiency anemia in Ondo State is still high. Prevalence and mortality resulting from iron deficiency anemia in children can be prevented not only by encouraging mothers to eat iron-rich foods of animal origin right from the time of pregnancy but by also educating them to always feed their babies with ageappropriate complementary foods rich in nutrients that could furnish their body system with the required iron.

Key words: Iron Deficiency Anemia, Prevalence, Ondo State, Food, Mortality
\end{abstract}

\section{Introduction}

The World Health Organization considers iron deficiency as the number one nutritional disorder in the world ${ }^{1}$. As many as $80 \%$ of the world's population may be iron deficient, while $30 \%$ may have iron deficiency anemia ${ }^{2}$. Anemia is prevalent in the developing countries with highest incidence reported in Asia and Africa ${ }^{3}$. Global prevalence of anemia in preschool aged children is $47.4 \%, 41.8 \%$ in pregnant women and $30.2 \%$ in non pregnant women ${ }^{4}$. In Nigeria, according to the UNICEF 1993 participatory information collection (PIC) studies, the prevalence rate for anemia in mother is $24 \%$. The highest prevalence of anemia in children was recorded in South Eastern Nigeria (49.6\%) and lowest (11.5\%) in Northern Eastern Nigeria.

Iron deficiency develops gradually and usually begins with a negative iron balance, when iron intake does not meet the daily need for dietary iron. This negative balance initially depletes the storage form of iron while the blood hemoglobin level, a marker of iron status, remains normal. Iron deficiency anemia is an advanced stage of iron depletion. It occurs when storage sites of iron are deficient and blood levels of iron cannot meet daily needs. Blood hemoglobin levels are below normal with iron deficiency anemia ${ }^{1}$. Iron deficiency anemia can be associated with low dietary intake of iron, inadequate absorption of iron, or excessive blood loss 5 . Women of childbearing age, pregnant women, preterm and low birth weight infants, older infants and toddlers, and teenage girls are at greatest risk of developing iron deficiency anemia because they have the greatest need for iron ${ }^{1}$. Poor nutrition especially iron deficiency in school aged children affects neurological development by decreasing learning ability with retardation of growth ${ }^{6}$.

\section{Aim of the study}

Information on the contribution of infant feeding practices and how it contribute to the prevalence and mortality from iron deficiency anemia of under five children has not been well documented in Ondo State, Nigeria. Therefore, this study was carried out to find out the prevalence and mortality of iron deficiency anemia in children within the age of 0-5 years and the implication of infant feeding practices on this. 


\section{Study Population:}

The study was carried out in Ondo State Nigeria. Four state specialist hospitals owned by Ondo State government were used for the study. The State which is made up of 18 local government areas is located in the South western zone of Nigeria. The State lies in the tropics with population of about 3,441,024 according to 2002 census. The State has four Specialist hospitals namely; State specialist hospital Ondo, in Ondo west local government area and State specialist hospital Akure, in Akure South local government area are both located in the Central Senatorial district of the State while State specialist hospital, Okitipupa, in Okitipupa local government area and State specialist hospital, Ikare in Akoko North West local government area, are located in the Southern Senatorial district and Northern Senatorial district of the State respectively. The State which is made up of 18 Local Government Areas is located in the South Western Zone of Nigeria. The State lies in the tropics with population of about 3,441,024 according to 2002 census. The four hospitals serve as referral centers to the General hospitals across the State, so the four hospitals are good representations of the State for this research work.

\section{Sample Population}

The total number of deaths from iron deficiency anemia and the total cases of children that suffered from iron deficiency anemia between 2005 and 2009 were collected from the Medical Records department of the four hospitals. About fifty to seventy children who attended pediatric clinic and registered at the pediatric clinic of each hospital were included in the study. A simple random sampling technique was used to select thirty five mother-child pairs from each of the specialist hospitals to make a total of one hundred and forty (140) subjects used for the study.

\section{Subjects}

Records of cases of iron deficiency anemia and deaths of children of 0-5 years between 2005 -2009 were obtained from the Medical Records department of the hospitals. Equally, a total number of one hundred and forty (140) mothers with their children were also enlisted to know the effects of their feeding practices and food intakes on the prevalence and death from iron deficiency anemia in each hospital. Thirty five (35) children with their mothers were enlisted in each of the State specialist hospitals i.e. State specialist hospital, Ondo; State specialist hospital, Akure; State specialist hospital, Okitipupa and State specialist hospital, Ikare.

\section{Method of data collection}

Cases of IDA, records of death of children aged 0-5 years that suffered from IDA were obtained from case notes and statistical records from Medical Records department while their hemoglobin status was obtained from the laboratory of each hospital. A validated, well structured questionnaire that sought background information on socio-demographic data, complementary feeding practices, food intakes of the children and mothers were distributed to the mothers for completion. The consent of the mothers was earlier sought, and only children whose mothers consented participated in the study. Before the commencement of the study, ethical approval was obtained from the research ethical committee of each hospital.

\section{Method of data Analysis}

Data was analyzed using descriptive statistics to find the frequency and percentage while SPSS Software version 15 was used to determine the correlation between, food intakes, protein intakes, parent's education, parent's occupation and iron deficiency anemia.

\section{Results}

Table 1A shows the prevalence of iron deficiency anemia in children of 0-5 years between 2005 to 2009 in the State. It shows that prevalence was as high as $25 \%$ with 933 children being anemic within the studied years. State specialist hospital, Ondo recorded the highest prevalence with 461 (53\%) children suffered from iron deficiency anemia in 2009. Prevalence was lowest across the State in 2007 with only 17\% anemic children. Death status of children from iron efficiency anemia was highest across the State in 2006 with 29\% (81) child's death as shown in table 1B. Table 2 shows the hemoglobin status of the children where about $50 \%$ suffered from moderate anemia. State specialist hospital, Ondo also recorded the highest number of mortality in 2009 with $74.6 \%$ (44) death. Table 3 shows the social-demographic data of the subjects used relation with the prevalence of anemia in the State. Forty seven percent (47\%) of the subjects were males and 53\% were females. Ninety three percent (93\%) were between the ages 0f 0-3 years while 7\% were aged 4-5 yearss. Most of the mothers (54\%) obtained secondary school education, 26\% tertiary education and 19\% primary education. Clinical data were presented in table 4 . It shows that $29 \%$ had blood transfusion while $71 \%$ never had transfusion of blood. It can be seen that the majority of mothers, 55\% gave iron supplements to prevent iron deficiency anemia, $30 \%$ used iron-enriched food while $15 \%$ used local herbs to prevent anemia in their children. 
Table 5 reveals that $17 \%$ of mothers introduced complementary food at 4 months, $9 \%$ at 12 months while $71 \%$ at 6 months. The table also shows that great number of mothers $76 \%$ continued with breastfeeding when they introduced complementary feeding. The animal protein consumption of children is presented in table $6.40 \%$ of children were fed with meat/fish once daily, $23 \%$ twice daily while $8 \%$ were fed 4-5 times daily. Majority of mothers, about $54 \%$ often feed their children with milk, $17 \%$ gave yoghourt, as low as $16 \%$ gave liver. $13 \%$ mothers agreed the baby was small as reason for not giving meat/fish, $8 \%$ said they have no money while 5\% complained that meat/fish was expensive. Table 7 shows that $36 \%$ of the children were often fed with pap+ milk, $16 \%$ with pap + soymilk, $26 \%$ with pap + crayfish while $18 \%$ were fed with commercial formula. Food taboo practices and foods disliked by mothers when pregnant are presented in table $8.29 \%$ of mothers were banned by taboos from eating certain foods while $71 \%$ did not have any food taboo. When pregnant, $17 \%$ of mothers disliked egg, $20 \%$ disliked fish while $9 \%$ disliked meat as can be seen in table 8 .

Table 1a: Prevalence of Anemia in four selected hospitals of Ondo State, Nigeria between 2005 and 2009

\begin{tabular}{lllllllllll}
\hline YEAR & AKURE & \% & ONDO & \% & IKARE & \% & OKITIPUPA & \% & TOTAL & \% \\
\hline & & & & & & & & & & \\
$\mathbf{2 0 0 5}$ & 63 & 9.9 & 173 & 42.8 & 152 & 23.8 & 150 & 23.5 & $\mathbf{6 3 8}$ & $\mathbf{1 6 . 9}$ \\
$\mathbf{2 0 0 6}$ & 131 & 19.2 & 281 & 41.1 & 134 & 19.6 & 137 & 20.1 & $\mathbf{6 8 3}$ & $\mathbf{1 8 . 1}$ \\
$\mathbf{2 0 0 7}$ & 166 & 25.2 & 237 & 36.1 & 142 & 25.5 & 114 & 17.3 & $\mathbf{6 5 9}$ & $\mathbf{1 7 . 5}$ \\
$\mathbf{2 0 0 8}$ & 149 & 16.0 & 463 & 49.6 & 200 & 21.4 & 121 & 13.0 & $\mathbf{9 3 3}$ & $\mathbf{2 4 . 8}$ \\
$\mathbf{2 0 0 9}$ & 22 & 2.6 & 461 & 53.0 & 207 & 24.2 & 165 & 19.3 & $\mathbf{8 5 5}$ & $\mathbf{2 2 . 7}$ \\
\hline TOTAL & $\mathbf{5 3 1}$ & & $\mathbf{1 7 1 5}$ & \multicolumn{8}{c|}{$\mathbf{8 3 5}$} & $\mathbf{6 8 7}$ & $\mathbf{3 7 6 8}$ & $\mathbf{1 0 0}$ &
\end{tabular}

Table 1b: Death resulting from Anemia in four selected hospitals of Ondo State, Nigeria between 2005

\begin{tabular}{|c|c|c|c|c|c|c|c|c|c|c|}
\hline YEAR & AKURE & $\%$ & ONDO & $\%$ & $\begin{array}{l}\text { and } 2 \\
\text { IKARE }\end{array}$ & $\%$ & OKITIPUPA & $\%$ & TOTAL & $\%$ \\
\hline 2005 & 7 & 10.8 & 30 & 46.2 & 7 & 10 & 21 & 32.3 & 65 & 23.2 \\
\hline 2006 & 26 & 32.1 & 37 & 45.7 & 9 & 11.1 & 9 & 11.1 & 81 & 28.8 \\
\hline 2007 & 1 & 2.0 & 19 & 38 & 5 & 10 & 25 & 50 & 50 & 17.8 \\
\hline 2008 & 2 & 8.0 & 18 & 72 & 4 & 16 & 1 & 41 & 25 & 8.9 \\
\hline 2009 & 3 & 5.1 & 44 & 74.6 & 5 & 84.7 & 7 & 11.9 & 59 & 21.3 \\
\hline TOTA & 39 & & & 30 & & 63 & 280 & & 100 & \\
\hline
\end{tabular}

Table 2: Hemoglobin Status of children that suffered from Anemia between 2005 \&2009 CLASSES OF ANEMIA

PREVALENCE

$\begin{array}{ll}\text { Mild } \quad(\mathrm{Hb} \leq 10 \mathrm{~g} / \mathrm{dl}) & 1863(49 \%)\end{array}$

\begin{tabular}{ll}
\hline Moderate $(\mathbf{H b} \mathbf{7 - 1 0 g} / \mathrm{dl})$ & $\mathbf{1 9 0 0 ( 5 0 \% )}$ \\
\hline Severe $\quad(\mathrm{Hb}<7 \mathrm{~g} / \mathrm{dl})$ & $415(11 \%)$
\end{tabular}

\begin{tabular}{|c|c|c|c|c|c|}
\hline Characteristics & No & $\%$ & Characteristics & $\mathbf{N}$ & $\%$ \\
\hline AGE & & & Sex of Child: & & \\
\hline $0-3$ years & 130 & 92.9 & Male & 66 & 47.1 \\
\hline $4-5$ years & 10 & 7.1 & Female & 74 & 52.9 \\
\hline Total & 140 & 100 & Total & 140 & 100 \\
\hline Age of Mother & & & $\begin{array}{l}\text { Family } \\
\text { Structure }\end{array}$ & & \\
\hline $20-27$ yrs & 66 & 47.1 & Single Mother & 19 & 13.6 \\
\hline $30-39$ yrs & 60 & 42.9 & Both Parents & 119 & 85.0 \\
\hline $40-50 \mathrm{yrs}$ & 14 & 10.0 & Guardian & 2 & 1.4 \\
\hline Total & 140 & 100 & Total & 140 & 100 \\
\hline
\end{tabular}




$\begin{array}{lll}\text { Number of Siblings } & \mathbf{N} & \mathbf{\%} \\ 1-2 & 91 & 65.0 \\ 3-4 & 27 & 19.3 \\ 5-6 & 6 & 4.3 \\ >6 & 1 & 0.7 \\ \text { None } & 10 & 10.7 \\ \text { Total } & \mathbf{1 4 0} & \mathbf{1 0 0}\end{array}$

Father's

Mother's

Occupation

Occupation

Civil servant

$45 \quad 32.1$

Private Business

32.1

Civil servant

17.1

Private 51

36.4

Farmers

Trader

$23 \quad 16.4$

Unemployed

6.4

Business

Farmers

7.1

Others

9

6.4

Trader

25.7

Total

$3 \quad 2.1$

Father's

100

Qualification

Primary

140

Unemployed

13.6

Others

0

$\begin{array}{lll}\text { Total } & 140 & 100\end{array}$

Mother's

Qualification

Secondary

Tertiary

25

17.9

Primary

19.3

Secondary $\quad 76 \quad 54.3$

None formal

45.0

$\begin{array}{ll}63 & 45.0 \\ 49 & 35.0\end{array}$

Tertiary

26.4

No Formal

0

Total

140

2.1

Total

37

100

Table 4: Distribution of children by clinical data: Blood Transfusion Status

Anemia Prevention Adopted for children

\begin{tabular}{lcllll}
\hline Response & Total & \% & Characteristics & Total & \% \\
& & & Blood & 76 & 54.3 \\
Yes & 35 & 25.0 & supplement & & \\
No & 105 & 75.0 & Iron rich foods & 42 & 30.0 \\
& & & Local herbs & 21 & 15.0 \\
Total & $\mathbf{1 4 0}$ & $\mathbf{1 0 0}$ & & 1 & 0.7 \\
\hline
\end{tabular}

Table 5: Distribution of children by complementary feeding practices: $\mathbf{n = 1 4 0}$

\begin{tabular}{llllll}
\hline Months & No & \% & Characteristics & No & \% \\
\hline $\begin{array}{l}\text { Duration of } \\
\text { Breastfeeding }\end{array}$ & \multicolumn{5}{l}{$\begin{array}{l}\text { Introduction of } \\
\text { Complementary } \\
\text { food }\end{array}$} \\
$0-2$ & 3 & 2.1 & & \\
$3-5$ & 13 & 9.3 & 4 Months & 24 & 17.1 \\
$6-8$ & 39 & 27.9 & 6-7 Months & 99 & 70.7 \\
$9-12$ & 17 & 12.1 & 12 Months & 12 & 8.6 \\
Did not breastfeed & 67 & 47.9 & None & 5 & 3.6 \\
Total & $\mathbf{1 4 0}$ & $\mathbf{1 0 0}$ & Total & $\mathbf{1 4 0}$ & $\mathbf{1 0 0}$ \\
Did you stop breastfeeding when you introduced complementary feeding? & & \\
Yes & 34 & 24 & & \\
No & 106 & 76 & & \\
Total & $\mathbf{1 4 0}$ & $\mathbf{1 0 0}$ & & \\
\hline \multicolumn{7}{r}{} \\
\hline
\end{tabular}


Table 6: Distribution of children by consumption of animal protein foods: $n=140$

\begin{tabular}{lll}
\hline Response & No & \% \\
\hline $\begin{array}{l}\text { Daily Meat/Fish } \\
\text { Consumption }\end{array}$ & & \\
& & \\
& & \\
Once & 54 & 40 \\
2 times & 24 & 17.1 \\
3 times & 23 & 16 \\
$4-5$ times & 11 & 7.9 \\
None & 26 & 19 \\
Total & $\mathbf{1 4 0}$ & $\mathbf{1 0 0}$
\end{tabular}

Reasons for not giving meat/fish Baby still small No money

Expensive

Gave meat/fish

Total

\begin{tabular}{|c|c|c|c|c|c|}
\hline \multicolumn{3}{|l|}{$\begin{array}{l}\text { Reasons for not } \\
\text { giving meat/fish }\end{array}$} & \multicolumn{3}{|c|}{ Protein food intake of children } \\
\hline Baby still small & 13 & 9.2 & Yoghurt & 24 & 17 \\
\hline No money & 8 & 5.7 & Milk & 75 & 54 \\
\hline Expensive & 5 & 3.6 & Liver & 23 & 16 \\
\hline Gave meat/fish & 114 & 88.4 & Never & 18 & 13 \\
\hline Total & 140 & 100 & Total & 140 & 100 \\
\hline Response & No & $\%$ & Response & No & $\%$ \\
\hline Beans & 52 & 37.1 & Pap + Milk & 50 & 35.7 \\
\hline Mashed yam & 16 & 11.4 & $\begin{array}{l}\text { Pap + Soy } \\
\text { Milk }\end{array}$ & 22 & 15.7 \\
\hline Custard & 15 & 10.7 & Pap + Crayfish & 36 & 25.7 \\
\hline Pap & 44 & 31.4 & $\begin{array}{l}\text { Commercial } \\
\text { baby food }\end{array}$ & 18 & 12.9 \\
\hline None & 13 & 9.3 & None & 14 & 10.0 \\
\hline Total & 140 & 100 & Total & 140 & 100 \\
\hline \multicolumn{6}{|c|}{ Daily intake of fruits by children } \\
\hline Once & 23 & 12.9 & & & \\
\hline Twice & 31 & 16.4 & & & \\
\hline 3 times & 40 & 22.1 & & & \\
\hline 4-5 times & 28 & 28.6 & & & \\
\hline None & 18 & 20.0 & & & \\
\hline Total & 140 & 100 & & & \\
\hline
\end{tabular}

Table 7:Distribution of children by types of traditional complementary food intakes:n=140

Table 8: Distribution of Mothers by food consumption during pregnancy: $n=140$

\begin{tabular}{llllll}
\hline Response & No & \% & Response & No & \% \\
\hline $\begin{array}{l}\text { Food taboo practices } \\
\text { Of mother }\end{array}$ & & $\begin{array}{l}\text { Foods disliked } \\
\text { by mothers }\end{array}$ & & \\
Yes & 40 & 29 & Egg & 24 & 17.1 \\
No & 100 & 71 & Fish & 28 & 20.0 \\
Total & 140 & 100 & Meat & 9 & 6.4 \\
& & & None & 79 & 56.4 \\
& & & Total & $\mathbf{1 4 0}$ & $\mathbf{1 0 0}$ \\
\hline
\end{tabular}

\section{Discussion}

Few studies have been conducted on prevalence and mortality caused by iron deficiency anemia in children of $0-5$ years in Western Nigeria. This study is the first comprehensive study to find out the prevalence/death from iron deficiency anemia and the contribution of infant feeding practices, food intakes on this important public health problem in Ondo State, Nigeria. Over 600 cases of iron deficiency anemia in children under five were recorded each year across the State. The study revealed the prevalence of IDA in Ondo 
State in 2008 and 2009 to be $25 \%$ and $23 \%$ respectively. This shows that the prevalence of anemia in Ondo State gradually moved from mild prevalence between 2005 and 2007 to moderate prevalence between 2008 $2009^{4}$. This result supports WHO/UNICEF report, 1993 that anemia prevalence rates are increasing in Nigeria and WHO report, 2007 which indicates anemia to be causing mild health problem and moderate health problem when prevalence is $5-19 \%$ and $20-39 \%$ respectively ${ }^{7}$. The study equally put the death status at 280 from 20052009. Mortality was highest in 2006 with $29 \%$ (88) deaths recorded from IDA. It is evident from the study that most mothers prevented anemia by giving their children iron or blood supplements while some used local herbs at the expense of iron-rich diet .The believe is that this would enable them to meet iron requirement of their children. Overdependence of mother and child on iron supplements to prevent anemia could be linked to iron deficiency. Brigham et'al, 1993 and CDC Recommendations, 1998 encouraged that iron supplementation should only be indicated when diet alone cannot restore deficient iron levels to normal and it is important for anyone who is considering taking an iron supplement to first consider whether their needs are being met by natural dietary needs ${ }^{8,1}$. In addition, herbs contain anti-nutritional factors like tannin, phytate that could prevent the absorption of iron in the body ${ }^{9}$. The study shows prevalence of iron deficiency anemia despite the fact that the majority of mothers practiced exclusive breastfeeding and even continued with breastfeeding with the introduction of complementary feeding. The reason may be because breastfeeding is low in iron, since iron store in breast milk can only sustain the child from birth to 6 months ${ }^{9}$. Iron deficiency is considered unlikely in normal children younger than 6 month because the iron deposits accumulated during uterine life augment the iron needs of infants when dietary intake is low until about 4-6 months of life ${ }^{9}$. Therefore, exclusive breastfeeding is recommended for the six month of life .However, gradual introduction of iron enriched solid foods should complement breast milk from 7 to 12 month. We can see in the study that most of the children were introduced to plain pap, pap + milk or milk only, either as protein food or as complementary weaning foods. Meat/fish and liver which are excellent sources of heme iron and enhancing factors for non-heme iron absorption, were consumed but in low quantities ${ }^{11}$. The study also shows that father's occupation was significant with the types of traditional food given to child at $\mathrm{p}=0.01$ level while father's education education was negatively correlated with the type of traditional complementary foods given to child. Protein food given to child and mother's education was significant at $\mathrm{p}=0.05$ level in state specialist hospital, Ondo. The reason for this may not be farfetched, because in developing countries like Nigeria, Food provision and consumption of nutritious foods by any family is depending largely on the income of the father while mother's income is meant to support the father in many occasions. Poor economic potential as indicated by lack of money and expensive nature of these protein foods, explained the low consumption of meat/fish by the children ${ }^{11}$. Fruits intake seemed to be high but the consumption pattern coupled with poor knowledge of nutrition did not allow the effects of vitamin $\mathrm{c}$ on iron bio-availability among these children to be effective ${ }^{11}$.

\section{Recommendation/ Conclusion}

Continuous nutrition education and the teaching of mothers on how to enrich infant traditional complementary diet with iron should be developed at all levels according to the recommendation to combat iron deficiency anemia.

\section{References}

[1] CDC Recommendations to prevent and control iron deficiency in the United States. Centers for Disease Control and Prevention (1998). MMWR Recomm Rep; 47:1-29.

[2] Stoltlzfus RJ, Chway HM, Montressor A, Tielsh JM, Jape JK, Albinico M and L Savioli. (2004). Low dose daily iron supplementation improves iron status and appetite but not anemia, whereas quarterly anthelminthic treatment improves growth appetite and anemia in Zanzibari pre school children. J. Nutr.; 134: 348-356.

[3] Tatala S. Svanberg U and B Mduma (1998). Low dietary iron available is a major cause of anemia, a nutrition survey in the Lindi District of Tanzania. Am. J.Clin. Nutr.; 68 171-178.

[4] Erin Mclean, Mary C, Ines E, Daniel W and Bruno de Benoist (2007). Worldwide Prevalence of Anemia in preschool aged children, Pregnant women and non-pregnant women of reproductive age. Sight and Life Magazine.

[5] Tapiero H, Gate L, Tew KD.(2001). Iron: deficiencies and requirements. Biomed Pharmacother.55:324

[6] Pollit E. (1997). Iron deficiency and education deficiency. Nutr.Rev.55;133-141

[7] World Health Organization (1993). Indicators for assessing iron deficiency and strategies for prevention. WHO/UNICEF/UN. Technical workshop. WHO, Geneva, Switzerland

[8] Brigham DE, Beard JL, Krimmel RS, Kenney WL. (1993). Changes in iron status during competitive season in female collegiate swimmers. Nutrition; 9:418-22.

[9] Breastfeeding and the use of human milk. American Academy of Pediatrics. 1997. Work Group on Breastfeeding. Pediatrics; 100:1035-9.

[10] Oski FA. (1993). Iron deficiency in infancy and childhood. New England Journal of Medicine 329: 190 - 93.

[11] Onimawo IA, Ukegbu PO, Asumugha VU, Anyika JU, Okudu H, Echendu CA, Nkwoala C and P. Emebu. (2010). Assessment of anemia and iron status of school aged children (aged 7-12) in rural communitiea of Abia State, Nigeria.Afr. J.Fd, Ag,Nutr \& Devt.8;1-9 